\title{
MAPK7 wt Allele
}

National Cancer Institute

\section{Source}

National Cancer Institute. MAPK7 wt Allele. NCI Thesaurus. Code C51258.

Human MAPK7 wild-type allele is located in the vicinity of $17 \mathrm{p} 11.2$ and is approximately 6 $\mathrm{kb}$ in length. This allele, which encodes mitogen-activated protein kinase 7 protein, plays a role in the activation of nuclear transcription factors in response to extracellular signals. The MAPK7 gene is overexpressed in prostate cancer. 